Tér és Társadalom 19. évf. 2005/3-4. 171-185. p.

Tér és Társadalom

XIX. évf. 2005 3-4: 171-212

\title{
KITEKINTÖ
}

\section{A MONETÁRIS INTEGRÁCIÓ REGIONÁLIS HATÁSAI}

\author{
(Regional Effects of the Monetary Integration)
}

\author{
FERKELT BALÁZS
}

Kulcsszavak:

monetáris integráció területi egyenlötlenségek konvergencia

A monetáris integráció és a terulleti egyenlótlenségek közötti kapcsolat már az 1970-es években is vizsgálat tárgyát képezte. Jelen tanulmány célul tủzi ki a kérdéskör elemzését, mind a közgazdasági elméletek szintjén, mind pedig az európai integráció gyakorlatában. Feltételezhetô, hogy az Európai Unió keretei között megvalósiton Gazdasági és Monetáris Unió (a továbbiakban GMU) az egységes belsổ piac hiányosságai, valamint a tagországok és a régiók között már a közös pénz bevezetése elött fennálló egyenlötlenségek miatt nem képes hozzájârulni a gazdasági-társadalmi különbségek mérséklödéséhez.

\section{A monetáris integráció és a területi egyenlötlenségek kapcsolatának elméleti háttere}

A közgazdasági elméletekben a monetáris integráció és a területi egyenlötlenségek között az optimális valutaövezetek, a konvergencia-, a divergencia-, valamint az U-elmélet segítségével teremthetö kapcsolat.

Az optimális valutaövezetek elméletei közül egyedül Ishiyama 1975-ben megjelent tanulmánya (Ishiyama 1975) foglalkozik a fenti összefüggésrendszerrel. Ishiyama a korábbi ún. „egy-kritériumos” elméletektől eltérően, amelyek a legfontosabb feltételét igyekeztek meghatározni a monetáris unió sikeres müködésének, egy ország létező valutarendszeréből indult ki, és a monetáris integráció elönyeit és hátrányait határozta meg ezen ország szemszögéböl, egyfajta költség-haszon elemzést végezve. Tanulmányában a szerző négy nagyobb „költség-típust” különböztet meg, amelyeket a monetáris integráció bevezetése okoz: 1. A monetáris politikai autonómia elvesztése. 2. A fiskális politika autonómiájának korlátozása. 3. A munkanélküliség növekedése az árfolyam rögzítésének, valamint az infláció csökkenésének eredményeképpen. 4. A regionális egyenlötlenségek esetleges erösödése. Ez utóbbi jelenség okát Ishiyama abban látja, hogy nemzetközi szinten sokkal könynyebben valósul meg a tőke mozgása, mint a munkaeróé. Ezen kívül kiemeli, hogy a bérnövekedési ráták közötti különbség kisebb, mint a termelékenységnövekedésben megmutatkozó differencia. Mindebből pedig az a következtetés vonható le, hogy a versenyképességbeli különbség növekszik az egyes országok, régiók között. 
A másik nagyobb elméletcsoport (konvergencia-, divergencia-, U-elmélet) a gazdasági integráció fejlödése és a terủleti egyenlötlenségek alakulása közötti kapcsolatrendszert világítja meg. Ez a gondolatkör nem kifejezetten a monetáris unió bevezetésének hatásait vizsgálja, de alkalmazható ez utóbbi összefüggésre is, tekintettel arra, hogy a gazdasági integráció fejlödését az egyes elméletek a kereskedelem költségeinek csökkenésével jellemzik. A GMU, a közös pénz bevezetése egyértelmủen ilyen fejlödési lépcsőnek tekinthetö, amely megszünteti a kủlönbỏző valuták használatából eredỏ átváltási (konverziós), árfolyam-biztosítási (kockázatkezelési), valamint információs költségeket is. A költségcsökkenés mértékére vonatkozóan a szakirodalomban több kalkuláció is található, általában a GDP 0,3-0,8\%-ával (Hallet 1997) számolhatunk. A költségcsökkenés mértéke az egyes országok esetében különbỏző lehet, függ például az adott ország gazdasági nyitottságától. Önmagában a fenti összefủggés is azt támasztja alá, hogy a monetáris integráció megvalósítása eltérően érinti az egyes tagországokat. Az országos szint mellett, ugyanezen logika alapján a régiókra gyakorolt eltérő hatás is igazolható, tekintettel arra, hogy azok gazdasági nyitottsága is különböző mértékủ. Ezt a megállapítást bizonyítja a Németország szövetségi tartományi (Bundesland)' exportnyitottsági mutatóit tartalmazó táblázat.

\section{TÁBLÁZAT}

Németország tartományi szintü export-nyitottsági mutatói (export/GDP) százalékban, 2004

(Indexes of Open-Export (Export/GDP) of Germany on Province Level, 2004)

\begin{tabular}{lclc}
\hline \multicolumn{1}{c}{ Tartomány } & $\begin{array}{c}\text { Export- } \\
\text { nyitottság }\end{array}$ & \multicolumn{1}{c}{ Tartomány } & $\begin{array}{c}\text { Export- } \\
\text { nyitottság }\end{array}$ \\
\hline Baden-Württemberg & 35,79 & Niedersachsen & 30,55 \\
Bayern & 30,65 & Nordhrein-Westfalen & 27,41 \\
Berlin & 12,83 & Rheinland-Pfalz & 33,19 \\
Brandenburg & 12,14 & Saarland & 40,28 \\
Bremen & 50,60 & Sachsen & 20,31 \\
Hamburg & 26,65 & Sachsen-Anhalt & 13,41 \\
Hessen & 19,05 & Schleswig-Holstein & 21,87 \\
Mecklenburg-Vorpommern & 10,05 & Thüringen & 17,46 \\
\hline
\end{tabular}

Forrás: Statistisches Bundesamt Deutschland (2005a, 2005b) alapján saját számítások.

Németország tartományai között 40 százalékpontos különbség figyelhető meg a legmagasabb nyitottsági mutatóval rendelkezỏ Bremen, és a legzártabb Mecklenburg-Vorpommern között. A tartományok között három NUTS II régió is található: a 12,83\%-os nyitottságot mutató Berlin, az 50,6\%-os értéket mutató Bremen, valamint Hamburg 26,65\%-os nyitottsággal. Ugyanígy eltérỏ az egyes régiók euróövezeten belüli nyitottsága is.

A konvergenciaelmélet leegyszerüsítve úgy fogalmazható meg, hogy a gazdasági integráció kialakulása, fejlődése a tényezöárak folyamatos kiegyenlítődése, valamint a fokozódó tényezőáramlás segítségével a konvergencia folyamatát erősíti (Hallet 1997; Martin 1998; Martin-Straubhaar 2001). Konvergenciaelméleten (és 
Tér és Társadalom 19. évf. 2005/3-4. 171-185. p.

ez a megállapítás igaz a divergenciaelméletre is) nem egy konkrét modellt, egy konkrét elméletet, de nem is egy szervezett irányzatot kell értenünk, sokkal inkább olyan elméletek összességét, amelyek különböző gazdasági jelenségeket, makromutatókat elemeznek, ezekre vonatkozóan az országok, illetve régiók között az egyenlötlenségek csökkenését mutatják, prognosztizálják. A konvergenciaelmélet a neoklasszikus növekedés-, és külkereskedelem-elméletekre vezethetö vissza. A Solow-féle neoklasszikus növekedéselmélet több ponton is érintkezik a konvergencia jelenségével. Solow modellje (Solow 1956) arra enged következtetni (már csak abból is kiindulva, hogy a technológiai színvonal exogén tényező, illetőleg hogy a technológia gyorsan terjed), hogy amennyiben nincs sokk-helyzet, és megfelelően müködnek a kiegyenlítỏ mechanizmusok, az országok egy före jutó jövedelmének növekedési rátája fordítottan arányos az országok kezdeti jövedelemszintjével, vagyis „abszolút konvergencia” valósulhat meg (Barro 1989). Ez a csökkenő hozadék érvényre jutását jelenti, vagyis ahol a tőke szintje alacsonyabb, ott azonos beruházási ráta nagyobb növekedést eredményezhet (Erdös 2003). Tekintettel arra, hogy a fenti feltételek a valóságban meglehetősen kis valószínüséggel teljesülnek együttesen, illetve, hogy ha Solow modelljét szigorúan értelmezzulk, az állapítható meg, hogy az egyes országok jövedelme saját egyensúlyi állapotukhoz konvergál, vagyis ,feltételes konvergencia” következik be (Mankiw-Romer-Weil 1990). Mindezeken kívül Erdős (2003) kiemeli, hogy a fejlettebb technika átvétele is a konvergencia folyamatát erősíti, különösen, ha megvalósul az áru, a munkaerő és a tỏke szabad áramlása. (A $\sigma$ - és $\beta$-konvergencia számításának módszertana is, ami fontos szerepet játszik a regionális egyenlötlenségek alakulásának értékelésében, a fenti modellböl vezethető le.)

A divergenciaelmélet középpontjában azon elgondolás áll, miszerint a gazdasági integráció fejlődése, a kereskedelmi költségek csökkenése következtében az agglomerációs tendenciák erősödnek, amit a centrumtérség irányába történő tényezőáramlás is jelez. A centrumtérségek megerősödésével a területi egyenlőtlenségek növekednek (Hallet 1997; Martin 1998; Martin-Straubhaar 2001). Az elmélet az új (endogén) növekedéselméletekre, a telephelyelméletekre, a regionális fejlődéselméletekre (ezen belül is Myrdal polarizációs elméletére), valamint az új gazdaságföldrajz és az új külkereskedelem-elméletre egyaránt visszavezethető. Krugman új gazdaságföldrajz-elméletében (Krugman 1991, 2003) a centrum-periféria viszony kialakulásának és fenntartásának irányába két centripetális erő hat: ,a vállalatok igénye arra, hogy a nagyobb piac közelében helyezkedjenek el”, valamint „a munkások igénye arra, hogy hozzáférjenek a többi munkás által termelt javakhoz" (Krugman 2003, 123). Ezzel szemben egy centrifugális erő azonosítható: a vállalatok azon törekvése, hogy a periférián lévő mezőgazdasági területeket is elláthassák. Krugman szerint amennyiben elég nagy a feldolgozóipar mérethozadéka, alacsony a szállítási költség, és elég nagy a természeti eröforrásokhoz nem kötött feldolgozóipar aránya, a feldolgozóipari termelés egy területen koncentrálódik, vagyis a centripetális erők érvényesülnek, ami a divergencia folyamatát jelenti. 
A konvergencia-, és a divergenciaelmélet ellentétes állításai között az U-elmélet teremt összhangot. (Krugman-Venables 1990, 1995) Ennek lényege, hogy a kereskedelemhez kapcsolódó költségek csökkenése (az integrációs szint fejlödése) több szakaszra bontható. A költségek közepes mérséklödése a centrum-periféria viszony kialakulásának, az egyenlötlenségek növekedésének irányába hat. A költségek további csökkenése következtében azonban, egy következỏ szakaszban a korábbi divergencia miatt kialakult alacsony bérszínvonal már kellőképpen vonzó lesz, így megindul az ipari tevékenységek fejlesztése a periférián, ami a konvergencia erösödését jelenti. Az egy före jutó jövedelmek és a tranzakciós költségek összefüggése egy U-alakú görbével ábrázolható. (Vagyis az integráció fejlődésének folyamatában először a divergencia, majd a konvergencia erősödése tapasztalható.)

\section{A monetáris integráció elönyei és hátrányai}

A monetáris integrációval foglalkozó szakirodalom [ld. pl.: De Grauwe (2000), Palánkai (2001), Lörincné (2001)] az új integrációs fokozat megvalósításának alábbi előnyeit és hátrányait különbözteti meg: konverziós költségek megszűnése; árfolyam-ingadozás megszünte; árszint-stabilizáció, az inflációs ráták konvergenciája; kamatkonvergencia; aszimmetrikus sokkok veszélyének növekedése; nemzeti költségvetési politikák játékterének szúkülése; seignorage-bevétel-kiesés; valamint a nemzetközi valutalét. Az európai Gazdasági és Monetáris Unió tagállamai vonatkozásában feltételezhetö, hogy valamennyi előny és hátrány eltérő mértékben hat az egyes országokra és ezáltal az egyes régiókra is.

A konverziós költségek és az árfolyam-ingadozások megszünésének hatása többek között a költségek korábbi, GDP-ben kifejezett arányától, illetve a nemzeti valuta árfolyam-volatilitásától függ. Bár rövidtávon nem várható az inflációs ráták nagy mértékủ konvergenciája, a stabil árszint a korábban kockázatosabbnak ítélt országokban is kedvezö befektetői környezetet hozhat létre. A kamatkonvergencia a magasabb kezdeti kamatszinttel rendelkezỏ országok számára jelenthet növekedési többletet. A nemzeti szintú monetáris és árfolyam-politika közösségi szintre helyezésével az egyes országok egy sokkhatások esetén alkalmazható kiigazító mechanizmust veszítenek el. A merev munkaeröpiaccal rendelkezỏ kevésbé fejlett országok esetében nagyobb az aszimmetrikus sokkok bekövetkezésének valószínủsége. A nemzeti költségvetési politikák játéktere több okból is szủkül. Egyrészt a Stabilitási és Növekedési Paktum szigorú szabályainak következtében, másrészt pedig a monetáris integrációban az egyes országok nemzeti fiskális politikái által a többi tagországra gyakorolt hatások miatt. A játéktér módosulása jelentős mértékben függ az államadósság és az államháztartási hiány mértékétől. A közös pénz bevezetésével a pénzteremtés kizárólagos joga a nemzetek feletti jegybank kezébe kerül. A seigniorage-bevételek alakulása meglehetösen nagy különbségeket mutatott a 90-es években, egyes országokban a GDP 2-3\%-át is elérte. (Igaz, hogy a tagországok nem a teljes bevételtỏl esnek el, de a Maastrichti Szerződés szerinti nyereségfelosztási rendszer nem felel meg az egyes országok korábbi bevételeinek.) A nem- 
zetközi valutalét sokrétú hatásokkal járhat: növelheti a seigniorage-bevételeket, ugyanakkor árfolyam-felértékelődést is maga után vonhat. [A hatások részletes elemzését bövebben ld. Ferkelt (2005)].

Nehezen állapítható meg egyértelmüen, hogy az egyes hatások az eurózónában a konvergencia vagy a divergencia irányába mutatnak. Négy hatás esetében valószínüsíthetö a kapcsolat: a konverziós költségek megszünése, valamint a kamat-konvergencia az egyenlötlenségek mérséklődéséhez, míg az aszimmetrikus sokkok veszélyének növekedése és a seigniorage-bevétel-kiesés a különbségek fokozódásához vezethet.

\section{A konvergencia, a fejlettségi különbségek alakulása az Európai Unióban és az euró-övezetben}

A konvergencia fogalma többféle értelmezésre ad lehetöséget. Jelenthet egymáshoz közelítést, de értelmezhető egy konvergenciapont elérésére történö törekvésként is. (Ezen belül a konvergenciapont megválasztása is több szempontból értelmezhető) ${ }^{2}$. A monetáris integráció nézőpontjából kockázatot jelent az adott gazdasági tér heterogenitása (a jelentős gazdasági-társadalmi egyenlőtlenségek megléte), a konvergencia tehát itt az egymáshoz közelítés, a különbségek csökkentése értelemben alkalmazandó elsősorban. (A különbségek csökkentése itt nem csak azok szintjére, hanem szerkezetének változására is vonatkozik.)

Az európai Gazdasági és Monetáris Unió alapját képező Maastrichti Szerződés az euró bevezetésének (a GMU harmadik szakaszába lépésének) feltételeként a konvergencia-kritériumok teljesítését szabta meg. Ezek a kritériumok azonban kevéssé a reálgazdasági teljesítményt veszik alapul, és figyelmen kívül hagyják a területi egyenlötlenségek, a gazdasági-társadalmi különbségek szintjét, illetve alakulását is. Ráadásul a feltételek nem a konvergencia erösödésének folyamatát, hanem egy időpontban történő fennállását (általában a vizsgálat előtti egy évre vonatkozóan) vizsgálják. A szakirodalom [ld. pl. ICEG (2005)] a maastrichti feltételrendszert nominális konvergencia-mutatóknak is nevezi. Ezzel szemben megkülönböztethetünk reál-konvergencia mutatókat, mint pl.: egy före jutó GDP, bérköltség alakulása, termelékenység, stb. Fontos megjegyezni, hogy 1998-ban még a maastrichti kritériumok teljesítését sem vizsgálták szigorúan és az egyes országok értékei jelentỏs eltéréseket mutattak [Id. bövebben: Ferkelt (2000)].

A fejlettségi különbségek vizsgálatának alapjául országos és regionális szinten az egy főre jutó, vásárlóerö-paritáson számított GDP-adatok szolgáltak. ${ }^{3}$ A szóródási mérőszámok mellett a különböző konvergencia-mutatókat választottam vizsgálati módszernek. A nemzetközi szakirodalom a fejlettségi különbségek vizsgálatára a $\sigma$ és $\beta$ - konvergencia módszerét egyarảnt alkalmazza. Ebben a fejezetben országos és regionális szinten mindkét vizsgálati módszer segítségével végzek számításokat. A monetáris integrációt illetően indokoltabbnak tartom mindazonáltal a $\sigma$-konvergencia ${ }^{4}$ használatát, tekintettel arra, hogy itt nem egy adott szinthez történő felzárkózásnak kell a középpontban lennie, sokkal inkább az egyenlötlenségek csökkenésének. 


\section{TÁBLÁZAT}

Az egy före jutó országos GDP-értékek (PPP) átlaga, szórása és relatív szórása (Average, Dispersion and Relative Dispersion of GDP Datas (PPP) per Capita of the Country)

\begin{tabular}{lrrrrrrrrr}
\hline & 1995 & 1996 & 1997 & 1998 & 1999 & 2000 & 2001 & 2002 & 2003 \\
\hline Átlag EU-15 $(€)$ & 18127 & 18947 & 20113 & 21073 & 22587 & 23227 & 23993 & 24780 & 25027 \\
Átlag EUR-12(€) & 18017 & 18767 & 19975 & 20983 & 22450 & 23125 & 23883 & 24708 & 24942 \\
Átlag EUR-11 (€) & 18600 & 19355 & 20600 & 21645 & 23218 & 23927 & 24682 & 25455 & 25636 \\
Szórás EU-15(€) & 4229 & 4298 & 4717 & 4965 & 5717 & 6242 & 6220 & 6297 & 6435 \\
Szórás EUR-12 (€) & 4650 & 4710 & 5188 & 5473 & 6338 & 6948 & 6931 & 7031 & 7185 \\
Szórás EUR-11 (€) & 4416 & 4478 & 4967 & 5236 & 6061 & 6704 & 6689 & 6874 & 7108 \\
Rel. szór. EU-15 & 0,23 & 0,23 & 0,23 & 0,24 & 0,25 & 0,27 & 0,26 & 0,25 & 0,26 \\
Rel. szór. EUR-12 & 0,26 & 0,25 & 0,26 & 0,26 & 0,28 & 0,30 & 0,29 & 0,28 & 0,29 \\
Rel. szór. EUR-11 & 0,24 & 0,23 & 0,24 & 0,24 & 0,26 & 0,28 & 0,27 & 0,27 & 0,28 \\
\hline
\end{tabular}

Forrás: Barcellan (2000, 2002a, 2002b); Kuhnert (2003) és Biedma (2005) alapján saját számítások.

A 2. táblázat az országos szintű adatok átlagának, szórásának, illetve relatív szórásának alakulását mutatja. Mindhárom vizsgált területen folyamatosan növekedett az egy före jutó GDP átlaga. [A legmagasabb értéket a tizenegy tagú (Görögország nélkül számított) eurózónában mérték.] A szórás és relatív szórás értékek 1999-ben és 2000-ben is növekedtek, 2001-ben és 2002-ben csökkenés tapasztalható, majd 2003-ban ismét emelkedés figyelhető meg. A legnagyobb különbségek a tizenkét tagú eurózónában húzódtak és húzódnak napjainkban is. A relatív szórás mindegyik országcsoport esetén magasabb volt 2003-ban, mint a közös pénz bevezetése elött, 1995-ben vagy 1998-ban. (Görögország és Spanyolország esetében növekedett az egy före jutó GDP az eurózóna átlagához viszonyítva, míg Portugáliánál csökkenés tapasztalható. Görögország 2003-ban „megelőzte” Portugáliát a fejlettségi rangsorban.) Hasonló tendencia látható a $\sigma$-konvergencia-vizsgálat eredményeinek ábrázolásakor is (1. ábra).

\section{1. ÁBRA}

A $\sigma$-konvergencia alakulása 1995 és 2003 között

(The Formation of $\sigma$-cconvergence between 1995 and 2003)

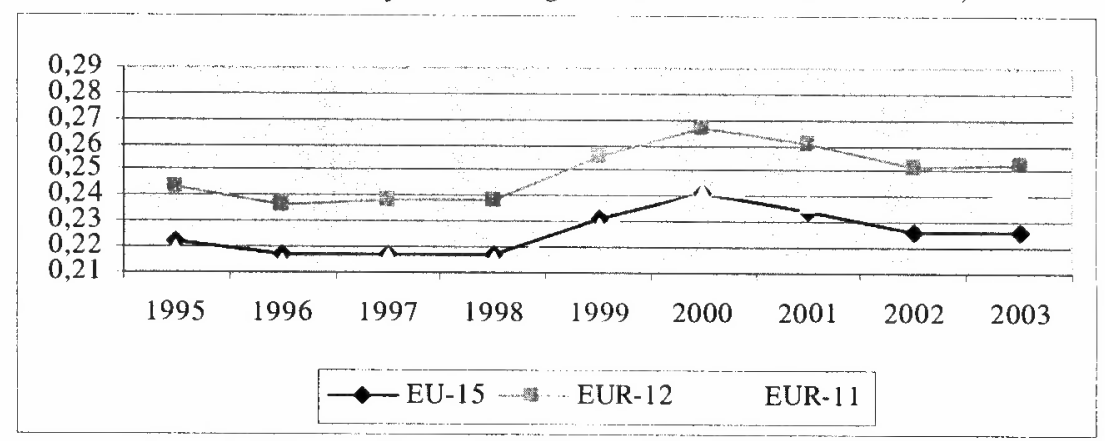

Forrás: Barcellan (2000, 2002a, 2002b); Kuhnert (2003) és Biedma (2005) alapján saját számítások és szerkesztés. 
A $\sigma$-konvergencia ${ }^{5}$ értékének alakulása alapján több szakasz különböztethető meg. 1995 és 1998 között enyhe csökkenést, stagnálást figyelhetünk meg. 1999-ben és 2000-ben a $\sigma$-konvergencia-mutató értéke növekedett, mindez a különbségek emelkedésére utal, 2001-2002-ben enyhe csökkenést láthatunk, majd 2003-ban a kis mértékü emelkedés ellenére is a konvergencia erőssége minden országcsoport esetében alacsonyabb, mint 1995-ben vagy 1998-ban, az euró bevezetése előtt. Érdekes, hogy a tizenegy tagú eurózónában növekedtek legerősebben a különbségek. Mindezek arra engednek következtetni, hogy az euró bevezetésével nem erösödött a konvergencia szintje az eurózóna országai között.

A $\beta$-konvergencia számítás alapjául az alábbi regressziós egyenes szolgált (A számításokat a Microsoft Excel XP program adatelemzỏ funkciója segítségével készítettem.):

$$
\ln y_{(2003)}-\ln y_{(1995)}=c-\beta \mid \mathbf{n}_{(1995)},
$$

ahol y az egyes országok fejlettségi szintjét (egy főre jutó, vásárlóerö-paritáson számított GDP-jét) mutatja, c konstans, míg $\beta$ a konvergencia mérỏszáma (a regressziós egyenes meredeksége). A 3. táblázat az elsősorban a felzárkózást jellemzỏ $\beta$-konvergencia vizsgálatának eredményét, illetöleg a regressziós modellek együtthatóit mutatja be.

\begin{tabular}{lccc}
\multicolumn{5}{c}{$\begin{array}{c}\text { 3. TÁBLÁZAT } \\
\text { Regressziós modellek együtthatói (országos szint) } \\
\text { (Coefficients of Regression Modells (Country Level) }\end{array}$} \\
\hline \multicolumn{1}{c}{ EU-15 } & $1995-2003$ & $1998-2003$ & $1995-1998$ \\
\hline Konstans értéke & 1,0186 & 0,1782 & 0,4944 \\
$\beta$ értéke & $-0,0713$ & $-0,0009$ & $-0,0350$ \\
$\mathrm{R}^{2}$ & 0,0265 & $8,183 \mathrm{E}-06$ & 0,0394 \\
\hline \multicolumn{1}{c}{ EUR-12 } & $1995-2003$ & $1998-2003$ & $1995-1998$ \\
\hline Konstans értéke & 0,7844 & $-0,0319$ & 0,4557 \\
$\beta$ értéke & $-0,0472$ & 0,0203 & $-0,0308$ \\
$\mathrm{R}^{2}$ & 0,0124 & 0,0051 & 0,0330 \\
\hline \multicolumn{1}{c}{ EUR-11 } & $1995-2003$ & $1998-2003$ & $1995-1998$ \\
\hline Konstans értéke & 0,3092 & $-0,6449$ & 0,4650 \\
$\beta$ értéke & 0,0007 & 0,0811 & $-0,0317$ \\
$\mathrm{R}^{2}$ & $2,484 \mathrm{E}-06$ & 0,0667 & 0,0264 \\
\hline Forrás: Barcellan & $(2000,2002 \mathrm{a}$, & $2002 \mathrm{~b})$, Kuhnert & $(2003)$ és
\end{tabular}

Biedma (2005) alapján saját számítások.

Az együtthatók közül $\beta$ értéke azt mutatja, hogy összességében az EU-15-ök terén 1995 és 2003 között megfigyelhető a konvergencia erősödése ( $\beta$ értéke negatív). A vizsgált időszak ugyan meglehetösen rövid, így két részre osztása csak nagyon óvatos következtetések levonását teszi lehetỏvé. Ha külön vizsgáljuk a GMU har- 
madik szakaszának kezdete előtti és utáni idöszakokat, akkor 1998 és 2003 között nem kapunk szignifikáns értéket. A tizenkét tagú eurózónában lényegesen kisebb felzárkózás tapasztalható, mint az EU-15 esetén, ráadásul az 1998-2003 közötti időszak a különbségek növekedésére utal. Ha Görögországot kihagyjuk a vizsgálatból a tizenegy ország fejlettségi szintje 1995 és 2003 között egyáltalán nem közelített egymáshoz. A modellben $\mathrm{R}^{2}$ igen alacsony értéke arra enged következtetni, hogy a kiindulási szint nem határozza meg a 2003-as fejlettségi szintet, vagyis nem valószínüsíthető a kevésbé fejlett országok felzárkózásának megvalósulása, ugyanakkor a fejlettebb országok relatív (az EU-15 átlagához viszonyított) fejlettségi szintjének csökkenése is bekövetkezhet. Mindezek miatt érdemes megvizsgálni külön is az egyes tagországok relatív fejlettségi szintjének (egy főre jutó, vásárlóerö-paritáson számított GDP az EU-15-ök százalékában) alakulását. 1995 és 2003 között kilenc ország javított relatív fejlettségi pozícióján (Ausztria, Egyesült Királyság, Finnország, Görögország, Hollandia, Írország, Luxemburg, Spanyolország és Svédország), míg hat ország esetében csökkent a mutató értéke (Belgium, Dánia, Franciaország, Németország, Olaszország, Portugália). (Hasonló csoportosítást kapunk, ha az 1998 és a 2003 közötti idöszakra vizsgálódunk, egyedül Franciaország kerülne át az első kategóriába.) A kezdeti fejlettségi szint és a növekedési ütem között mindösszesen egy nagyon gyenge, negatív irányú kapcsolat mutatható ki.

A regionális szintü vizsgálat pontosabb képet adhat a fejlettségbeli különbségek alakulásáról. 2005 júliusában mindösszesen 2002-ig álltak rendelkezésre az egy fóre jutó GDP-adatok ${ }^{6}$. A fejlettségi szint átlaga (4. táblázat) 1995 és 2002 között folyamatos növekedést mutat, bár 2002-re a dinamika csökkent. A szórás értéke is folyamatosan emelkedik, kivételt képez ez alól az eurózóna esetében a 2002-es év.

\section{TÁBLÁZAT}

Az egy fơre jutó regionális GDP-értékek (PPP) átlaga és szórása (Average and Dispersion of Regional GDP Datas (PPP) per Capita)

\begin{tabular}{lcccccccc}
\hline & 1995 & 1996 & 1997 & 1998 & 1999 & 2000 & 2001 & 2002 \\
\hline Átl. EU-15(€) & 16845,61 & 17678,71 & 18559,29 & 19352,72 & 20536,32 & 20794,63 & 21608,18 & 22174,78 \\
Átl. EUR-12(€) & 16867,82 & 17581,89 & 18457,65 & 19250,00 & 20333,65 & 20508,71 & 21209,43 & 21812,52 \\
Átl. EUR-11 (€) & 17390,88 & 18092,22 & 18975,41 & 19786,77 & 20950,40 & 21124,13 & 21779,46 & 22313,58 \\
Szór. EU-15(€) & 4890,583 & 5138,296 & 5346,218 & 5660,465 & 6075,209 & 6311,493 & 6473,492 & 6508,816 \\
Szór. EUR-12(€) & 4959,937 & 5175,972 & 5309,133 & 5564,475 & 5955,387 & 6044,6 & 6105,762 & 6081,778 \\
Szór. EUR-11(€) & 4793,69 & 5036,141 & 5182,285 & 5443,364 & 5783,138 & 5878,203 & 5992,917 & 6033,361 \\
\hline
\end{tabular}

Forrás: EUROSTAT (2005b, 2005c) és Stapel-Pasanen-Reinecke (2004) alapján saját számítások.

A relatív szórásértékekből kirajzolódó tendencia (2. ábra) alapvetően hasonlít az országos szintü vizsgálat eredményeihez, de a régiók esetében a különbségek nem növekedtek olyan erösen 1999-ben és 2000-ben. A 2001-2002-es csökkenö szakasz eredményeképpen az eurózónában az 1995-es vagy az 1998-as szinthez képest - ha minimális mértékben is - de alacsonyabb relatív szórást mértek. 


\section{2. ÁBRA}

A relatív szórás értéke NUTS II szinten

(Value of Relative Dispersion at NUTS II)

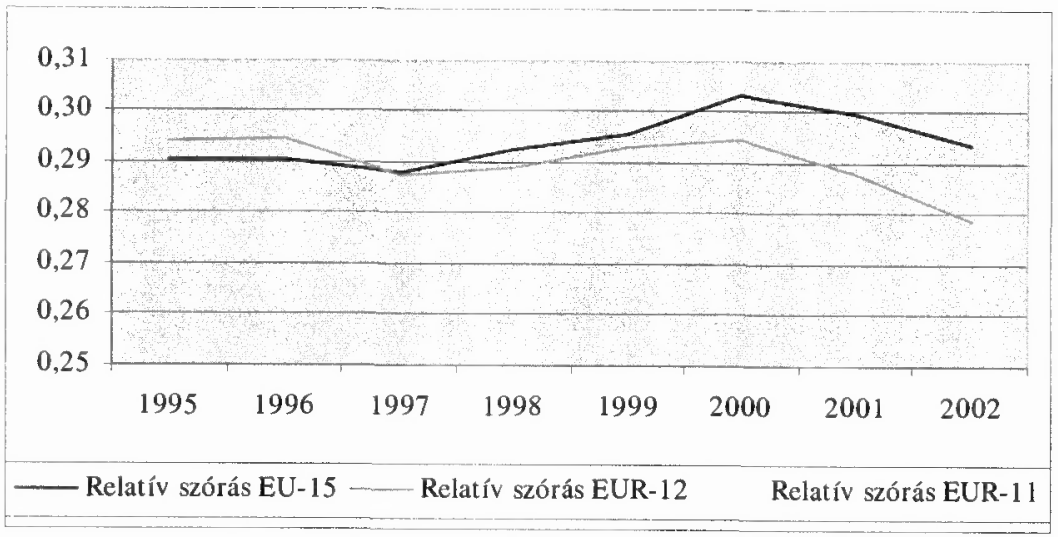

Forrás: A 4. táblázat adatai alapján saját szerkesztés.

A o-konvergencia (3. ábra) regionális szinten nagyobb különbségeket mutatott 1995-ben, mint tagországi szinten, és 1995-1997 között csökkenés figyelhető meg.

\section{3. ÁBRA}

A $\sigma$-konvergencia alakulása a régiók (NUTS II) szintjén (1995-2002)

(The Formation of $\sigma$-convergence at NUTS II Level of Regions, 1995-2002)

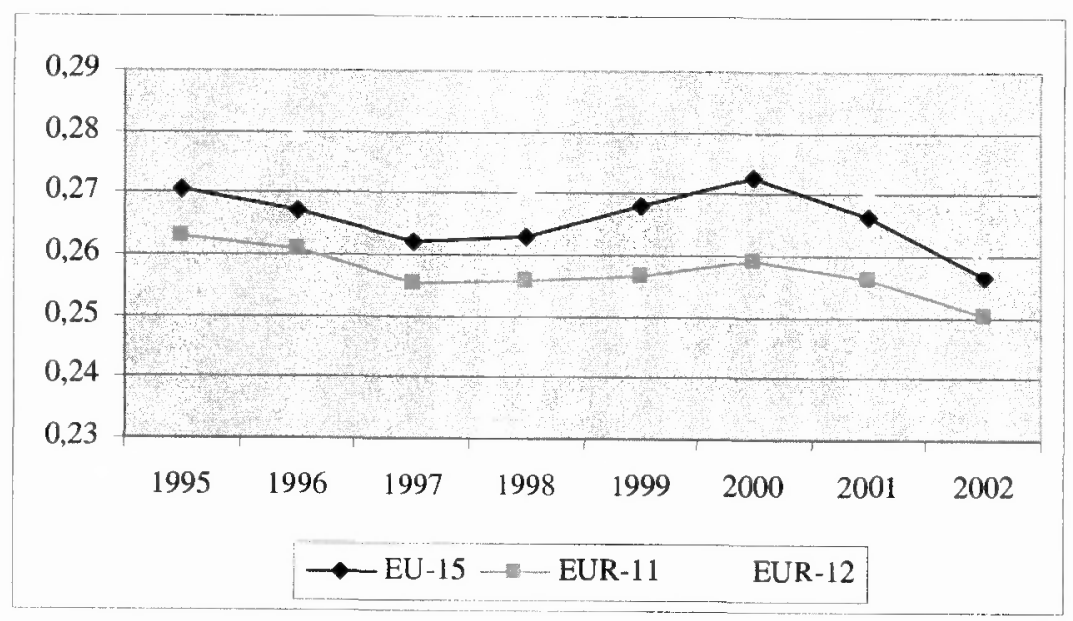

Forrás: EUROSTAT (2005b, 2005c) és Stapel-Pasanen-Reinecke (2004) alapján saját számítások és szerkesztés.

Az 1998 és 2000 közötti emelkedés kisebb mértékủ volt, mint az országos adatok esetében, majd 2001-ben és 2002-ben az eurózónában a konvergencia-mutató értéke 0,02-al csökkent. Ennek eredményeképpen 1998 és 2002 között összességében a 
regionális konvergencia erösödött, de igen kis mértékben, mindösszesen 0,01-al. Ettöl függetlenül még mindig az eurózónában a legnagyobbak a különbségek. (A teljes vizsgált időszakban, 1995 és 2002 között összességében lényegesen nagyobb volt a mérséklödés üteme.)

$\mathrm{Az}$ 5. táblázatban a régiók szintjén végzett $\beta$-konvergencia számítások eredményei láthatóak. Mind az Unió egészét, mind pedig az eurózónát tekintve megfigyelhetö, hogy 1995 és 2002 között regionális szinten összességében erösebb volt a felzárkózás, mint a tagországok esetében. Ha azonban összehasonlítjuk az euró bevezetése előtti és az azt követó idöszakot, lényeges különbségre, a felzárkózás dinamikájának növekedésére nem következtethetünk.

\section{TÁBLÁZAT}

Regressziós modellek együtthatói (regionális szint) (Coefficients of Regression Modells (regional level)

\begin{tabular}{lccc}
\hline \multicolumn{1}{c}{ EU-15 } & $1995-2002$ & $1998-2002$ & $1995-1998$ \\
\hline Konstans értéke & 1,3578 & 0,6105 & 0,5754 \\
$\beta$ értéke & $-0,1115$ & $-0,0481$ & $-0,0449$ \\
$\mathbf{R}^{2}$ & 0,0996 & 0,0427 & 0,0647 \\
\hline \multicolumn{1}{c}{ EUR-12 } & $1995-2002$ & $1998-2002$ & $1995-1998$ \\
\hline Konstans értéke & 1,6276 & 0,7960 & 0,7325 \\
$\beta$ értéke & $-0,1408$ & $-0,0680$ & $-0,0617$ \\
$\mathbf{R}^{2} \quad$ & 0,1852 & 0,0890 & 0,1551 \\
\hline \multicolumn{1}{c}{ EUR-11 } & $1995-2002$ & $1998-2002$ & $1995-1998$ \\
\hline Konstans értéke & 1,2153 & 0,5326 & 0,5582 \\
$\beta$ értéke & $-0,0991$ & $-0,0417$ & $-0,0440$ \\
$\mathrm{R}^{2}$ & 0,0941 & 0,0341 & 0,0786 \\
\hline
\end{tabular}

Forrás: EUROSTAT $(2005 \mathrm{~b}, 2005 \mathrm{c})$ és Stapel-Pasanen-Reinecke (2004) alapján saját számítások és szerkesztés.

A fejlettségbeli különbségek vizsgálata során tehát arra a következtetésre juthatunk, hogy a monetáris integráció megvalósítása során, az euró bevezetését követöen nem mérséklödtek érdemben (sőt országos szinten növekedtek) az eurózónán belüli különbségek. A fejlettségbeli különbségek az EU-15 és az EUR-12 térségben hasonlóképpen változtak, tehát az euró bevezetése nem okozott eltérö tendenciát. Hasonlóképpen, a felzárkózást jellemzö $\beta$-konvergencia vizsgálat elvégzését követỏen is megállapítható, hogy az euró bevezetése nem segítette eló érdemben a kevésbé fejlett országok, régiók felzárkózását. 


\section{Kitekintés}

2004. május elsején az Európai Unió tíz kelet-, kelet-közép és dél-európai országgal bövült. Ennek következtében az integráció lakossága 19\%-al, GDP-je viszont mindösszesen 4\%-al bővült [A 2004-es GDP-adatok alapján (EUROSTAT 2005a, 2005d)]. Ebböl két következtetés is levonható: 1. A kibővítés jelentősen megnövelte a fejlettségi különbségeket. 2 . Az új tagországok gazdasági súlya igen csekély az integráció egészét tekintve, tehát gazdasági fejlödésük, mutatóik a huszonöt tagú Unió makromutatóinak súlyozott átlagértékeit csak kis mértékben befolyásolják.

Az új tagországok elméletileg legkorábban 2007-ben vezethetik be az eurót. Az egyes országok különböző menetrendet készítettek GMU-csatlakozásukat illetően, a tervezett időpontok általában 2007 és 2010 közé esnek. Terveik komolyságát mutatja, hogy 2005 augusztusában hat ország: Ciprus, Észtország, Lettország, Litvánia, Málta és Szlovénia nemzeti valutái már az árfolyam-lebegtetési mechanizmus (ERM II.) tagjai voltak. A konvergenciakritériumok teljesítése terén meglehetősen vegyes a kép. Érdekes, hogy a rendszerváltozást legkorábban megkezdett, legfejlettebbnek számító visegrádi országok küzdenek leginkább a maastrichti kritériumok teljesítésével. A monetáris és a fiskális kritériumok egyaránt problémát jelentenek. Előbbi teljesítését a magasabb növekedés, a dinamikus fogyasztásnövekedés, valamint a Balassa-Samuelson hatás nehezíti, míg utóbbi betartását a közös költségvetésbe történő befizetés, a támogatásokhoz kapcsolódó nemzeti társfinanszírozás és komoly infrastrukturális fejlesztési, valamint különböző reform (társadalombiztosítás, egészségügy stb.) szükségletek hátráltatják.

A térség országai, régiói és a régi tizenöt tagország között jelentős fejlettségi kùlönbségek húzódnak, ha az egy före jutó, folyó áron és vásárlóerö-paritáson számított GDP értékeket összehasonlítjuk. 2003-ban a tíz országból mindösszesen kettő érte el vagy haladta meg a közösségi átlag 70\%-át, a legfejletlenebb Portugália fejlettségi szintjét pedig három csatlakozó ország (Ciprus, Málta és Szlovénia) tudta felülmúlni. Ezen országok csatlakozása az EU-tagállamok vásárlóerö-paritáson számított GDP-jének egyszerü átlagát a 2003-as adatokat figyelembe véve 5000 euróval csökkentette, a szórást mintegy 1500 euróval növelte, a relatív szórás 0,14 -al emelkedett. ${ }^{7}$

Mindezeknek megfelelỏen a szigma-konvergencia értéke is nagymértékben emelkedett (0,15-al), ami a különbségek jelentős növekedésére utal. Az EU-10 gazdasági növekedésének átlaga jelentősen meghaladja az EU-15 növekedési rátáját, de az egyes országok eltérő fejlödési tendenciát mutatnak. A növekedési adatok (a gazdasági összteljesítménnyel, a GDP értékével) súlyozott átlaga (EU-25 és EU-15) 1996 és 2004 között sohasem tért el 0,1 százalékpontnál nagyobb mértékben. Az egyszerủ számtani átlag számításakor azonban jól érzékelhetỏ az újonnan csatlakozott országok növekedési többlete, különösen 2002 és 2004 között, amikor ez a többlet a 2 százalékpontot is meghaladja. (A tíz ország csatlakozásának gazdaságpolitikai jelentősége lényegesen nagyobb, mint amekkorát a statisztikai súlyok mutatnak.) A legdinamikusabb gazdasági növekedést a balti országok tudhatják magukénak. 
Regionális szinten is komoly egyenlötlenségnövekedés következett be. Az EUROSTAT (2005e) számításai szerint újonnan csatlakozott országok 41 NUTS II régiója közül 23-nak a fejlettsége (egy före jutó vásárlóerö-paritáson számított GDP-je) nem éri el a 25-tagú Európai Unió átlagának 50\%-át. A 6. táblázat értékeiböl kiderül, hogy az új EU-régiók egyértelmủen növelik a különbségeket, még úgy is, hogy az elemzésben a 41 EU-10 régió az összes vizsgált régió számának 16,5\%-át tette ki. Az is megállapítható továbbá a számítások eredményeiből, hogy az újonnan csatlakozott tagországok régiói között is komoly különbségek húzódnak.

\section{TÁBLÁZAT}

Az EU-10, az EU-15, az EUR-12, az EU-25, valamint az EUR-22 egy före jutó, regionális GDP-jének (PPP) átlaga, szórása, relatív szórása, szigma-konvergencia-mutatója (Average, Dispersion, Relative Dispersion and Sigma-Convergence Index of Regional GDP Datas (PPP) per Capita of EU-10, EU-15, EUR-12, EU-25 and EUR-22)

\begin{tabular}{lclc}
\hline \multicolumn{1}{c}{ Mutató } & \multicolumn{1}{c}{2002} & \multicolumn{1}{c}{ Mutató } & 2002 \\
\hline Átlag EU-10 $(€)$ & 11952,38 & Relatív szórás EU-10 & 0,45 \\
Átlag EU-15(€) & 22174,78 & Relatív szórás EU-15 & 0,29 \\
Átlag EUR-12(€) & 21812,52 & Relatív szórás EUR-12 & 0,28 \\
Átlag EU-25(€) & 20484,79 & Relatív szórás EU-25 & 0,36 \\
Átlag EUR-22(€) & 19811,20 & Relatív szórás EUR-22 & 0,36 \\
Szórás EU-10 & 5432,10 & Szigma-konv. EU-10 & 0,35 \\
Szórás EU-15(€) & 6508,82 & Szigma-konv. EU-15 & 0,26 \\
Szórás EUR-12(€) & 6081,78 & Szigma-konv. EUR-12 & 0,26 \\
Szórás EU-25(€) & 7393,16 & Szigma-konv. EU-25 & 0,37 \\
Szórás EUR-22 & 7155,26 & Szigma-konv. EUR-22 & 0,38 \\
\hline
\end{tabular}

Forrás: EUROSTAT (2005b, 2005c) és Stapel-Pasanen-Reinecke (2004) alapján saját számítások.

Az újonnan csatlakozott tíz ország és legtöbb régiója még jelenleg (2005-ben) is a felzárkózás fázisában van. Amennyiben ezek az országok mostani növekedési ütemüket fenntartják, és 2010-ben csatlakoznak a GMU-hoz, még akkor is jelentösen növelnék az eurózónán belüli fejlettségi különbségeket, mind országos, mind regionális szinten. (A fejlettségi szint mellett hasonló, vagy még nagyobb eltéréseket mutatnak egyes reálkonvergencia-mutatók, melyek részletes elemzésétől most eltekintek.)

Megállapítható tehát, hogy a tíz új tagország, bár kereskedelmi kapcsolatait tekintve messzemenökig integrálódott az egységes belső piacba, a fejlettségi szint (és több nominális és reálkonvergencia-mutató) esetén jelentös lemaradást mutat a régi tizenöt tagországgal szemben. Korai GMU-tagságuk több veszélyt is magában hordozhat:

1. Jelentösen növekednek az eurózónán belüli egyenlötlenségek. A GMU eddigi múködése a fenti eredmények alapján nem kedvezett az országos és regionális különbségek csökkenésének. 
2. A közös monetáris politika elsődleges célkitủzése az árstabilitás fenntartása. Az árstabilitás mérése az egyes tagországok harmonizált inflációs rátáinak súlyozott átlagával történik. Az újonnan csatlakozott tíz ország meglehetősen csekély statisztikai súllyal bír. Fennáll tehát a veszély, hogy a közös monetáris politika elsősorban a nagyobb súllyal bíró (régi) tagországok gazdasági helyzetét fogja figyelembe venni, így az egyes intézkedések kevéssé segíthetik elő az új tagországok (és régiók) felzárkózását. (Ennek hatására a nemzeti költségvetési politikák szerepe, az államháztartás gazdasági súlya, szerkezete és funkciója is átértékelődhet.)

3. Az új tagországok alacsonyabb fejlettségi szintje, eltérő gazdasági szerkezete, munkaerö-piaci feszültségei következtében nőhet az aszimmetrikus sokkok veszélye az eurózónában.

A fenti elemzések és érvek alapján a tíz új tagországnak most sokkal inkább a felzárkózásra, semmint a maastrichti konvergencia-kritériumok erőltetett ütemủ teljesítésére kellene koncentrálniuk, és 2010 körül egy olyan eurózónához csatlakozni, ahol addigra már komoly erőfeszítéseket tettek az egyenlőtlenségek mérséklése érdekében.

\section{Összegzés}

A közgazdasági elméletekben (konvergencia-, divergencia-, U-elmélet) feltárható a monetáris integráció és a területi egyenlötlenségek összefüggésrendszere. A fenti elméletek megállapításai úgy is összegezhetőek, hogy ha a termelési tényezők megfelelỏen mobilak, tehát ha az egységes belső piac tökéletesen megvalósul, a monetáris integráció elősegíti a területi egyenlötlenségek mérséklödését. A monetáris integráció lehetséges előnyeinek és hátrányainak vizsgálata arra enged következtetni, hogy a közös pénz bevezetésének hatásai eltérő mértékben érintik az egyes tagországokat és közvetlenül vagy közvetve azok régióit is. A fejlettségi különbségek vizsgálata során arra az eredményre juthatunk, hogy a monetáris integráció nem járult hozzá egyértelmủen és jelentősen a területi egyenlötlenségek mérséklödéséhez. Az országos szinten mért egy före jutó GDP relatív szórása a vizsgált időszakban emelkedést mutatott, míg a régiók szintjén enyhe mérséklödés tapasztalható. A $\sigma$-konvergencia (amely az egyenlötlenségek általános szintjét vizsgálja) értéke az euró bevezetését követỏen emelkedett, ami a konvergencia szintjének mérséklődésére utal, majd 2001-ben a konvergencia erösödni kezdett. Országos szinten állnak rendelkezésre csupán 2003-as adatok, amelyek stagnálást mutatnak. A $\beta$-konvergencia (amely a felzárkózás ütemére koncentrál) szerint 1995 és 2003 között a kevésbé fejlett országok és régiók folyamatos felzárkózása valósult meg, de ennek dinamikája az euró bevezetése elött erősebb volt, mint 1999 után. Az, hogy a monetáris integráció nem segítette elő a konvergencia folyamatát, több okra is visszavezethetö, egyrészt az egységes belső piac hiányosságaira (a szolgáltatási piac nem teljes liberalizációjára, nem eléggé rugalmas, egységes munkaerőpiacra), másrészt pedig a GMU megvalósításának kezdete elött is tapasztalható komoly egyenlőtlenségekre. A fenti eredmények alapján megfogalmazható a közösségi területi ki- 
egyenlítő mechanizmusok, támogatások növelésének igénye. Az újonnan csatlakozott tíz ország GMU-tagsága jelentősen növelné az eurózóna heterogenitását, ugyanakkor a fenti vizsgálatok tapasztalatai alapján megkérdőjelezhető, hogy mennyire segítheti elő az euró bevezetése sikeres felzárkózásukat. Emiatt ezeknek az országoknak, így Magyarországnak is most sokkal inkább a folyamatos és dinamikus felzárkózásra és ezzel párhuzamosan a szükséges reformok véghezvitelére kellene koncentrálniuk, nem pedig az euró minél korábbi bevezetésére.

\section{Jegyzetek}

${ }^{1}$ A példa alapjául azért ezeket a régiókat választottam, mert Németországban tartományi szinten is rendelkezésre állnak megfelelö külkereskedelmi adatok.

${ }^{2}$ A konvergencia kuilönböző értelmezési lehetöségeiröl részletesebben ld. többek között Práger (2004) vagy Nemeskéri (2003).

3 tekinthető. Meg kell azonban jegyezni, hogy ezt az időpontot már egy több éves felkészülési idöszak elözte meg. Ennek megfelelöen az egyes jelenségeket, makromutatókat 1995-től (egyes mutatók esetén 1996-tól) kezdődően vizsgálom. A feltételezés helyességét az is igazolja, hogy a GMU harmadik szakaszának kezdetérỏl 1995 decemberében, Madridban született döntés, másrészt pedig megfelelően harmonizált statisztikák is ettől az idöponttól kezdve állnak rendelkezésre. (Ausztria, Finnország és Svédország is ekkor csatlakozott az Európai Unióhoz.) A területi egyenlötlenségek vizsgálatánál - különösen a statisztikai elemzéseknél - a monetáris integráció terủletén belül elsősorban a tagországi szintre és a tégió szintjére koncentrálok. Egy tizenkét, vagy ennél több tagú valutaövezet esetében egy-egy tagország egy-egy régiónak is tekinthetö. Az országos adatok bemutatásánál általában a tizenkét eurózóna tagországra (EUR-12), a tizenegy eurózóna tagországra (EUR-11, Görögország nélkül), valamint a tizenöt európai uniós tagországra (EU-15) vonatkozóan is találhatóak számítások. Mindenképpen meg kell itt jegyezni, hogy az EUR-12 és az EU-15 összehasonlítása nehéz feladat. Nem állapítható meg egyértelmủen, hogy az esetleges különbségek mennyire a GMU-n kívül maradásra és mennyiben a három ország sajátosságaira vezethetőek vissza.

${ }^{4} A$

A $\sigma$ - és a $\beta$-konvergencia számítási módszere egyaránt Solow neoklaszikus növekedési modelljéből vezethetỏ le. Részletesebben ld. Nemeskéri (2003).

${ }^{5}$ A $\sigma$-konvergencia az egyes (itt egy före jutó, vásárlóerö-paritáson számított GDP) értékek logaritmusảnak szórása.

Az egy főre jutó, vásárlóerő-paritáson számított regionális GDP-adatok részben saját számításokon alapulnak. Az EUROSTAT ugyanis mindösszesen az EU-15, illetve EU-25 átlagában adja meg az egyes régiók fejlettségi szintjét. Jelen adatok a régiók össz-GDP-jének és a lakosságszám hányadosának (az egy före jutó folyó áron számított GDP-nek) az adott ország vásárlóerö-szorzójával korrigált értékei.

${ }^{7}$ A relatív szórás 0,4-es értéke azt mutatja, hogy az átlag nem jellemzi megfelelően a sokaságot.

\section{Irodalom}

Barcellan, R. (2000) Das Bruttoinlandsprodukt 1998. Statistik kurz gefasst, Thema 2, 2/2000, Luxemburg.

Barcellan, R. (2002a) Das Bruttoinlandsprodukt 2000. Statistik kurz gefasst, Thema 2, 1/2002, Luxemburg. Barcellan, R. (2002b) Das Bruttoinlandsprodukt 2001. Statistik kurz gefasst, Thema 2, 53/2002, Luxemburg.

Barro, R. (1989) Economic Growth in a Cross Section of Countries. NBER Working Paper Series, No. 3120, Cambridge, Massachusetts.

Biedma, L. (2005) Das Bruttoinlandsprodukt 2003. Statistik kurz gefasst, Thema 2, 8/2005, Luxemburg. De Grauwe, P. (2000) Economics of Monetary Union. Oxford University Press.

Erdỏs T. (2003) Fenntartható gazdasâgi növekedés. Akadémiai Kiadó, Budapest.

EUROSTAT (2005a) BIP und Hauptkomponenten - Jeweilige Preise. http://epp.eurostat.cec.eu.int/portal/page? _pageid=1996,45323734\&_dad=portal\&_schema=PORTAL\&screen=welcomeref\&open=/nation/aggs/aggs gdp\&language=de\&product=EU_MASTER_national_accounts\&root=EU_MASTER_national_accounts\& scrollto=240 Letöltés ideje: $2005.07 .27 .17: 54$ 
EUROSTAT (2005b) Regionales Bruttoinlandsprodukt. http://epp.eurostat.cec.eu.int/extraction/retrievel de/theme1/regio/econr/esa95/gdp95/e2gdp95?OutputDir=EJOutputDir_1344\&user=unknown\&clientsessionid= 3C7BDCDAD0A7F38317842E0435DAA844.extraction-worker2\&OutputFile=e2gdp95.htm\&Output

Mode=U\&NumberOfCells=48\&Language=de\&OutputMime=text $\% 2 F$ tml\& Letöltés ideje: 2005. 07. 30, 17:22

EUROSTAT (2005c) Regionale Bevölkerung. http://epp.eurostat.cec.eu.int/extraction/retrieve/de/theme1/ regio/demor/d3avg?OutputDir=EJOutputDir_2939\&user=unknown\&clientsessionid=04EC420BE7A332F4 52673E500B25FF84.extractionworker1 \&OutputFile=d3avg.htm\&OutputMode=U\&NumberOfCells=45\&L anguage $=$ de \&OutputMime=tex1\%2Fhtml\& Letöltés ideje: $2005.08 .22 .8: 17$

EUROSTAT (2005d) Bevölkerung (Jahresdurchschnitt) nach Geschlecht und Alter.

http://epp.eurostat.cec.eu.int/extraction/retrieve/de/theme3/demo/dpop/ppavg?OutputDir=EJOutputDir_2 347\&user=unknown\&clientsessionid=42A645D4032F832ECFDF4D6243B72F75.extraction-worker1\&OutputFile=ppavg.htm\&OutputMode $=$ U\&NumberOfCells $=2646 \&$ Language $=$ de \&OutputMime= text\%2Fhtml\& Letöltés ideje: 2005. 08. 23. 12:13

EUROSTAT (2005e) Regionale Pro-Kopf-Aufschliusselung des BIP.

http://epp.eurostat.cec.eu.int/extraction/retrieve/de/theme0/sdi/sdi_ed1130?OutputDir=EJOutputDir_135 3\&clientsessionid=D9CE50F796D77633735122E0DD7F53F4.extraction-worker-2\&OutputFile= sdi_ed 130 .htm\&OutputMode=U\&NumberOfCells $=2032 \&$ Language $=$ de $\&$ OutputMime $=$ text $\% 2$ Fhtml \& Letöltés ideje: 2005. 06. 17. 13:34

Ferkelt B. (2000) A Gazdasági és Monetáris Unió elsö éve. Szakdolgozat, Pécsi Tudományegyetem, Közgazdaságtudományi Kar

Ferkelt, B. (2005) A közös monetáris politika hatása a területi egyenlötlenségekre és a regionális versenyképességre. Évkönyv 2004, Pécsi Tudományegyetem, Közgazdaságtudományi Kar, Regionális Politika és Gazdaságtan Doktori Iskola, Pécs. Megjelenés alatt.

Hallet, M. (1997) Wirkungen wirtschafticher Integration auf periphere Regionen - Eine Untersuchung anhand der Integration Griechenlands und Portugals in die Europäischen Gemeinschaften. Triere Schriftenreihe zur Wirtschaftstheorie und Wirtschaftspolitik, Band 6., Trier

ICEG Európai Központ (2005) Az új tagállamok konvergencia-indexe, 2005/1., Budapest

Ishiyama, Y. (1975) The Theory of Optimum Currency Areas: A Survey. - IMF Staff Papers. Vol. 22. 344-383. o.

Krugman, P. (1991) Increasing Returns and Economic Geography. - Journal of Political Economy. Vol. 99, 483-499. o.

Krugman, P. (2003) Földrajzés kereskedelem. Nemzeti Tankönyvkiadó, 2003

Krugman, P.-Venables, A. (1990) Integration and the Competitiveness of Peripheral Industry. CEPR Discussion Papers 363, London

Krugman, P.-Venables, A.J. (1995) Globalization and the Inequality of Nations. NBER Working Paper Series, No. 5098, Cambridge, Massachusetts

Kuhnert, I. (2003) Das Bruttoinlandsprodukt 2002. Statistik kurz gefasst, Thema 2, 56/2003, Luxemburg

Lörincné, Istvánffy H. (2001) Pénzügyi integráció Európában. KJK-Kerszöv, Budapest

Mankiw, N. G.-Romer, D.-Weil, D. N. (1990) A Contribution to the Empirics of Economic Growth. NBER Working Paper, No. 3541, Cambridge

Martin, R.-T. Straubhaar (2001) Regional Effects of EMU. - Caesar, R.-Scharrer, H.E. (ed.) European Economic and Monetary Union: Regional and Global Challenges. Nomos, Baden-Baden

Martin, R. (1998) Regional Policy in the European Union - Economic Foundations and Reality. Centre for European Policy Studies, Brussels

Nemeskéri, Zs. (2003) A régiók fejlódése és konvergenciája Kínában. PTE-TTK-FEEFI, Pécs

Palánkai, T. (2001) Az európai integráció gazdaságtana. Aula Kiadó, Budapest

Práger, L. (2004) Konvergencia-divergencia, leszakadás és felzárkózás. Kézirat, Budapest

Solow, R. (1956) A Contribution to the Theory of Economic Growth. - Quarterly Journal of Economics, Vol. 70, 65-94. o.

Stapel, S.-Pasanen, J.-Reinecke, S. (2004) Kaufkraftparitäten und abgeleitete Wirtschafisindikatoren fiir EU, Beitrittskandidaten und EFTA. Statistik kurz gefasst, Wirtschaft und Finanzen 37/2004, Luxemburg

Statistisches Bundesamt Deutschland (2005a) Deutschland als Handelspartner: Außenhandel Deutschlands nach Bundesländern 2004. www.destatis.de/basis/d/aussh/aushtabl.php Letöltés ideje: 2005. 08. 29. 11:02

Statistisches Bundesamt Deutschland (2005b) Volkswirtschaftliche Gesamtrechnungen - Bruttoinlandsprodukt http://www.statistik-portal.de/Statistik-Portal/de jb27 jahrtab65.asp Letöltés ideje: 2005. 08. 29. 11:03 